\title{
Coeliac disease presenting with a leuco-erythroblastic anaemia
}

\author{
B. T. COOPER \\ M.B., M.R.C.P.

\begin{abstract}
Summary
A 49-year-old Irishman presented as an emergency with watery diarrhoea and a leuco-erythroblastic anaemia. Investigations showed that he had coeliac disease but no evidence of bone marrow infiltration. His leuco-erythroblastic picture disappeared on treatment with iron and folic acid.
\end{abstract}

D. J. Evans

M.B., M.R.C.P.

\author{
V. S. Chadwick \\ M.D., M.R.C.P. \\ Clinical Gastroenterology Unit, Department of Medicine, Hammersmith Hospital, Du Cane Road, \\ London W12 OHS
}

\section{Introduction}

Anaemia is common in adults with coeliac disease at presentation and may be due to folate deficiency or less commonly to iron deficiency (Hoffbrand, 1974). The blood film usually reflects the type of anaemia. A patient with coeliac disease is described who presented with diarrhoea and a leuco-erythroblastic anaemia. So far as the authors know, this has not been described before.

\section{Case report}

A 49-year-old male Irish clerk presented as an emergency with a 3-week history of severe watery diarrhoea and abdominal pain. He had had 4 previous attacks of diarrhoea with abdominal pain and distension over the preceding 2 years, each attack lasting up to 5 weeks. Further questioning showed that he had been a 'sickly' child, was always the smallest of his family in height and weight, had a tendency to pass pale floating loose stools and suffered from recurrent aphthous ulceration of the mouth and excessive lassitude. On examination he was thin, clinically anaemic and dehydrated. His height was $157 \mathrm{~cm}$, and weight $45 \mathrm{~kg}$. The abdomen was distended and tender. After rehydration, his clinical state and diarrhoea improved. Further investigations were as follows:

$\mathrm{Hb}, 7 \cdot 8 \mathrm{~g} / \mathrm{dl}$; MCV, 79; MCH, 19.3 pg; reticulocyte count, $1.9 \%$ white cell and platelet counts normal; ESR, $43 \mathrm{~mm} / \mathrm{hr}$. The blood film showed a leucoerythroblastic picture with some target cells. Serum iron was $2.6 \mu \mathrm{mol} / 1$; serum transferrin, $3.25 \mathrm{~g} / 1$ 尔 serum folate, $4 \cdot 2 \mathrm{ug} / \mathrm{l}$; serum $B_{12}, 280 \mathrm{ng} / \mathrm{l}$. Boneio marrow examination showed a mixed megalo $\Rightarrow$ blastic and iron deficiency pattern. Splenic function tests showed a normal splenic size and good activity on splenic scan but prolonged clearance of damaged? red cells $-25 \mathrm{~min}$ (normal 10-16 min). The serum urea and electrolytes were normal. His serum albumin was $37 \mathrm{~g} / \mathrm{l}$; globulin, $25 \mathrm{~g} / \mathrm{l}$; calcium, $1.98 \mathrm{mmo} / 1$. phosphorus, $0.56 \mathrm{mmol} / 1$; alkaline phosphatase, 105 i.u./1; 25-hydroxycholecalciferol, $1.2 \mu \mathrm{gl}$ / (normak winter range 7-35 $\mu \mathrm{g} / \mathrm{l})$; bilibrubin $6 \mu \mathrm{mol} / 1$; aspa⿳亠丷厂巾tate transaminase, 30 i.u./1; $1 \mathrm{gG}, 11.3 \mathrm{~g} / 1 ; \operatorname{IgA}, 2 \cdot 34$ $\mathrm{g} / \mathrm{l} ; \mathrm{IgM}, 1 \cdot 16 \mathrm{~g} / \mathrm{l}$. His glucose tolerance test showed nos rise at $30 \mathrm{~min} ; 2.3 \%$ of a $25-\mathrm{g}$ oral xylose dose was excreted in $5 \mathrm{hr}$; and a Schilling test showed excretion of $7 \cdot 3 \%$ of the dose without intrinsic factor $\stackrel{\mathbb{Q}}{\mathbb{Q}}$ Faecal fat excretion on a 70-g fat intake was $15 \mathrm{~g} /$ day $\overrightarrow{\overrightarrow{0}}$ His barium follow-through was normal and a skel-응 etal survey showed no evidence of bone disease. Ajejunal biopsy was quite flat-consistent with a: diagnosis of coeliac disease. He was started on के gluten-free diet. After 3 months, he had no symp-3. toms and had gained $6 \mathrm{~kg}$ in weight. A repeat jejunato biopsy showed marked morphological improvement 3 . The blood film returned to normal within 2 days of starting oral folic acid and iron.

\section{Discussion}

Leuco-erythroblastic anaemia is defined as the presence in the peripheral blood of immature redo cells and immature white cells of the myeloid series 0 (Vaughan, 1936), but the mechanisms underlying this N appearance are not understood (Wintrobe, 1974). Ito has been thought to be almost diagnostic of marrow infiltration (Britton, 1963), but studies on large series of patients with a leuco-erythroblastic blood film? have shown that only one-third to 2-thirds of these 0 patients have this (Retief, 1964; Burkett, Cox andō 
Fields, 1965; Weick, Hagedorn and Linman, 1974). Other common causes include infection, haemolysis and haemorrhage. Leuco-erythroblastic anaemia has been described in megaloblastic anaemia, due to both pernicious anaemia and folate deficiency (Erklentz, 1935; Retief, 1964; Burkett et al., 1965) and in severe iron deficiency anaemia without haemorrhage (Burkett et al., 1965; Weick et al., 1974), although never before in anaemia due to coeliac disease. The blood picture in the present case could have been due to folate deficiency or to iron deficiency, or both. This case emphasizes the point that leuco-erythroblastic anaemia does not necessarily mean marrow infiltration and can occur with either megaloblastic or iron deficiency anaemia. Moreover, coeliac disease should be considered when a patient presents with a leuco-erythroblastic anaemia.

\section{References}

Britton, C.J.C. (1963) Disorders of the Blood. 9th edn, p. 202, Churchill Livingstone, London.

BurketT, L.L., CoX, L.M. \& FieldS, M.L. (1965) Leukoerythroblastosis in the adult. American Journal of Clinical Pathology, 44, 494.

ERKLeNTZ, B.W. (1935) Leukamoide Reaktion bei Leberremission einer Anaemia perniciosa. Folia haematologica, $53,382$.

Hoffbrand, A.V. (1974) Anaemia in adult coeliac disease. Clinics in Gastroenterology, 3, 71.

RETIEF, F.P. (1964) Leuco-erythroblastosis in the adult. Lancet, i, 639.

VAUghaN, J.M. (1936) Leuco-erythroblastic anaemia. Journal of Pathology and Bacteriology, 42, 541.

Weick, J.K., Hagedorn, A.B. \& Linman, J.W. (1974). Leukoerythroblastosis. Diagnostic and prognostic significance. Proceedings. Mayo Clinic, 49, 110.

Wintrobe, M.M. (1974) Clinical Hematology 7th edn, p. 1786, Lea and Febiger, Philadelphia. 